\title{
Managing raw materials in Vinča culture: a case study of osseous raw materials from Vitkovo
}

\author{
Selena Vitezović ${ }^{1}$, Jelena Bulatović ${ }^{2}$ \\ 1 Institute of Archaeology, Beograd, RS; \\ selenavitezovic@gmail.com \\ 2 Laboratory for Bioarchaeology, Department of Archaeology, Faculty of Philosophy, University of Beograd, RS \\ j.bulatovic@yahoo.com
}

\begin{abstract}
In analyses of material recovered from archaeological sites, a dichotomy often exists between 'specialist' and 'archaeological' studies. This is especially noticeable in the case of faunal remains and bone artefacts. Bone artefacts are sometimes treated separately from fauna with emphasis on typological data, or they can be left within the fauna with only a remark on 'other taphonomic traces', thereby overlooking technological features of these artefacts. However, bone industry provides excellent insight into technological choices regarding raw material exploitation, since the availability and mechanical properties of specific materials can be directly observed. In this paper we tried to link bone artefacts with other faunal remains on the basis of a case study of the Vinča culture site at Vitkovo with a special emphasis on the relations between butchering techniques and raw material selection and the relations between the economically most important species and the bones most commonly used in tool manufacture.
\end{abstract}

IZVLEČEK - Pri analizah materiala, ki se ga odkrije na arheoloških najdiščih, pogosto obstaja dvojnost med 'specialističnimi' in 'arheološkimi' študijami. To je še posebej izrazito pri analizah živalskih ostankov in artefaktov iz kosti. Kostni artefakti se včasih obravnavajo ločeno od preostale favne s poudarkom na tipologiji ali pa se jih obravnava skupaj s favno, vendar le z omembo 'drugih tafonomskih sledi, kar pomeni, da se s tem spregledajo tehnološke značilnosti teh artefaktov. Pa vendar nudi kostna industrija odličen vpogled v tehnološke odločitve pri izrabi naravnih materialov, saj lahko neposredno opazujemo dosegljivost in mehanične lastnosti specifičnih snovi. V članku poskušava povezati kostne artefakte z drugimi živalskimi ostanki na študijskem primeru vinčanskega najdišča Vitkovo. Pri tem posebej poudarjava odnose med praksami zakola in izborom naravnih materialov ter odnose med gospodarsko bolj pomembnimi vrstami in kostmi, ki se najpogosteje uporabljajo za izdelavo orodij.

KEY WORDS - faunal assemblage; bone industry; raw materials management; Vinča culture; central Balkans

\section{Introduction}

As a discipline that aims to reconstruct past modes of human life, archaeology must rely on numerous scientific methods developed in other disciplines, or created as a result of multi- and inter-disciplinary research. One area where archaeology has to rely on other sciences in particular is the analysis of raw materials, from the process of acquiring foodstuffs and raw materials for tool making, building shelters, or crafting other, utilitarian or non-utilitarian artefacts.
The analysis of raw material acquisition and management is the first and one of the most important steps in a technological analysis. The concept of technology as a culture-driven phenomenon implies the notion that more than one technology can usually satisfy the minimum requirements for any given task, and that the choice of a particular technology from among the alternatives may be strongly influenced by beliefs, social structure and the prior choi- 
ces of the given society (cf. Lemonnier 1992; 1993; Killick 2004).

Diverse theoretical concepts and methodologies for technological analysis have been developed, the main goal being to place technological phenomena in a socio-cultural context. Probably the most frequently used, and the one having the greatest interpretative potential, is the concept of the operational chain (chaîne opératoire) devised by André Leroi-Gourhan $(1964 ; 1965 ; 1971)$. This is an analytic technique that explores how an artefact is made, used and discarded: the acquisition of raw material, the choice of manufacturing technique, final shape, and use (which includes thesauring, breakage, repair, sequences of re-use), all the way through to the discarding of the object, and passing through all the stages of manufacture and use of different components. The concept of chaîne opératoire enables us to structure the use of materials by placing each artefact in a technical context, and offers a methodological framework for each level of interpretation. It also provides a dynamic perspective, because it takes into account all the stages in the life of an object. This concept allows us to reconstruct the organisation of technological systems and technological strategies through an understanding of the relations between raw material procurement, tool manufacture, tool use, maintenance and discard (Sellet 1993; Inizan et al. 1995.14).

The reconstruction of different steps within a chaîne opératoire also implies an analysis of technological choice: why a specific material was chosen and not some other; why specific manufacturing techniques were employed rather than different ones; why the object was discarded in a certain way, etc. The decision making may be limited by the natural environment, available knowledge, etc., but the solution is also selected in accordance with cultural and social preferences: some raw material may exist in the environment and yet remain unused. Numerous archaeological studies have been devoted to analysing the mechanisms that govern choices of technology.

B. Hayden (1998) suggested a division of technologies into the practical (i.e. techniques used to solve practical problems of survival and basic comfort) and the prestigious (those that display power, wealth and prestige and are used to perform a social task). One of the underlying principles in practical technology is to perform tasks (such as obtaining and processing food and raw materials, creating an adequate shelter and storage facilities) in an efficient and ef- fective way. For a given problem, the criteria used in choosing between alternative technological solutions are how effective and how costly each solution is and, in general, practical technology is a logical and empirical response to stresses in the environment. According to the design theory, different kinds of constraint operate in the development of solutions for each problem, and trade-offs between constraints make it unlikely that only a single optimal solution to a problem exists, but, rather, a number of more or less equally acceptable solutions. Among the most powerful of these constraints are functional requirements, material properties, availability, and production costs. Once a field of acceptable solutions for a given problem has been identified, the choice of solution to be adopted may largely be a matter of cultural tradition, ideological values, style, etc. (Hayden 1998).

Analysis of raw materials may provide information on the exploitation of the environment; relative distances of resources from settlements may indicate a territory controlled by a group, or, in the case of hunter-gatherers, migration routes and/or territory covered. The technology for extracting some raw materials such as stones or ores may indicate the level of technological knowledge and organisation within a community that explored them. Analyses of exotic raw materials (e.g., obsidian, Williams Thorpe 1995; Williams Thorpe et al. 1979; 1984) are an especially attractive field of research, as they may indicate routes and directions of trade and exchange ( $c f$. Dixon et al. 1968). Careful analyses of the use of certain raw materials may also reveal cultural preferences (or avoidance) and related cultural attitudes to them, as well as the crafts associated with them.

Numerous analyses of raw materials focus on lithic materials (e.g., Antonović 1997; Biró 1998; Gurova 2011 , to mention just a few), but the studies encompass a wide variety of raw materials (e.g., amber, Palavestra 1993; du Gardin 2002; Murillo-Barroso, Martinón-Torres 2012; salt, Weller 2012; Cavruc, Harding 2012; Saile 2012, and many more).

Analyses of osseous raw materials are not as abundant, although their number has increased in the past few decades (e.g., Guthrie 1983; Scheinsohn, Ferretti 1995; Margaris 2012; see also Choyke, Schibler 2007). Most of these focus on exotic materials (e.g., Spondylus shell, Dimitrijević, Tripković 2002; 2006; Borrello, Micheli 2004; tortoise shell, Rijkelijkhuizen 2010, etc.), but some other studies 
should also be mentioned. A study by Robert McGhee (1977) deals with raw material choices within the Thule culture in arctic Canada. McGhee clearly demonstrates that the use of antler, ivory and bone for specific artefacts is by no means accidental, and that it is in fact strictly linked to a worldview. From the relations between raw materials and their products, McGhee reconstructed the oppositions: land/ sea, summer/winter, man/women, antler/ivory.

Gaëlle le Dosseur (2010) studied raw material choices in the assemblages from Natufian, PPNA and PPNB periods in the southern Levant area, focusing on the choice of bones from domestic $v$ s. wild animals. Also, the problem of using raw materials from wild animals has been addressed by Ingrid Sénépart (1993) and Isabelle Sidéra (2000).

The choice of raw material may not necessarily reveal symbolic importance, but it may give insight into the economy; for example, the study by Jörg Schibler (2001) on lake-dwelling sites in Zürich showed a clear and direct relationship between the use of antler as a raw material and the hunting of red deer. In some periods of occupation, the proportion of antler tools was greater than bone tools, but in periods when juvenile red deer bones were abundant (and, subsequently large, strong antlers from adult individuals were not available), the proportion of antler artefacts was low.

\section{Vitkovo site}

The prehistoric site of Vitkovo is situated $3 \mathrm{~km}$ from Aleksandrovac in central Serbia, $25 \mathrm{~km}$ from Kruševac, in the valley of the River Stubalska, on the slopes of Vitkovo Field (Map). It was first discovered in the mid-20th century, and the first sondage excavations were carried out in 1969 and 1971. In 2001, small-scale rescue excavations were carried out

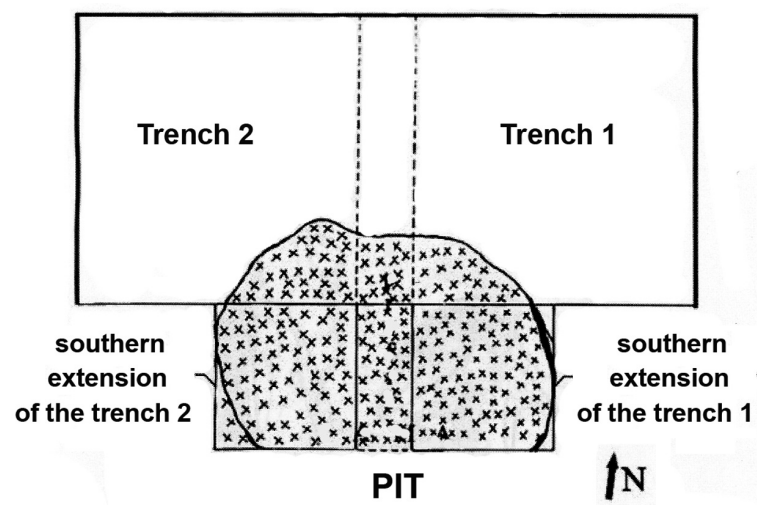

Fig. 1. The feature (pit) excavated in 2001.

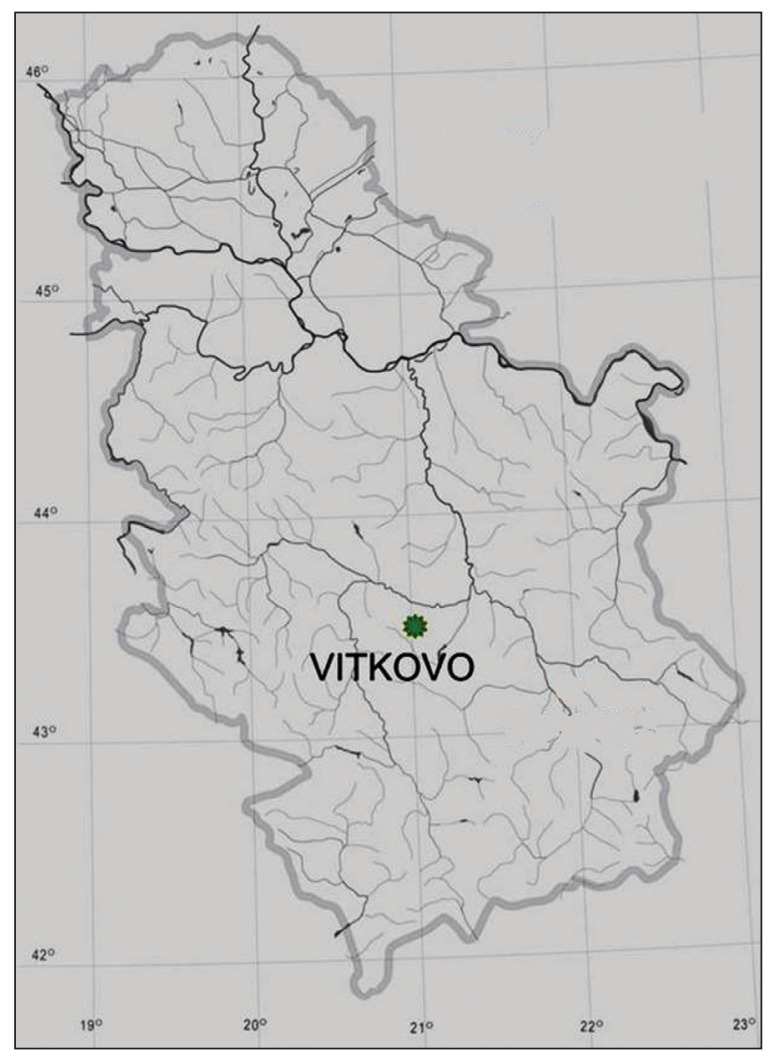

Map. The position of the Neolithic site of Vitkovo.

on the property of the Trifunovic family. Two trenches, the first $5 \times 5 \mathrm{~m}$, and the other somewhat larger, were excavated. One pit, probably a rubbish pit (Fig. 1), was discovered, approx. $4.80 \times 3.70 \mathrm{~m}$, and daub fragments were recovered in its vicinity, suggesting that a dwelling had been situated nearby. The content of the pit was comprised of ash and numerous portable items: stone and flint tools, pottery, terracotta figurines and altars, which dated the site to the later phases of the Vinča culture, to Vinča-Pločnik I (Čađenović et al. 2003; Čađenović 2007).

The careful collecting of animal bones also enabled the first faunal analysis (Bulatović 2011) and yielded a relatively large number of osseous artefacts, including manufacture debris (Vitezović 2011b).

\section{Materials and methods}

The faunal assemblage from Vitkovo was hand collected; it comprises the bones of mammals and birds (11 specimens) and bivalve shells (8 specimens). The distribution of various taxa of the animals is given by NISP (Number of Identified Specimens). The relative frequency based on NISP is calculated only for mammal remains which were identified at least to the genus level. Of the total of mammalian specimens collected (1838), identification up to the 
level of genus was completed for 471 fragments. The distribution of various skeletal elements is given for the most frequent taxa (ovicaprines, domestic cattle, domestic pig, and red deer). All the bones were carefully examined for traces of manufacture and/or use, and a total of approx. 50 artefacts were singled out for typological and technological analysis.

\section{The Vitkovo faunal assemblage}

The remains of 12 mammal species were identified in the Vitkovo faunal assemblage. The domestic species include sheep (Ovis aries), goat (Capra hircus), cattle (Bos taurus), pig (Sus domesticus) and dog (Canis familiaris), while the wild species were red deer (Cervus elaphus), roe deer (Capreolus capreolus), auroch (Bos primigenius), wild pig (Sus scrofa), hare (Lepus europeus), fox (Vulpes vulpes) and marten (Martes sp.). Domestic animals outnumber game (comprising $87 \%$ of NISP), and produced the most important and reliable meat supply. Based on the number of specimens identified (NISP), ovicaprines (sheep and goat) are the most frequent taxa (55.4\% NISP), followed by cattle (12.7\% NISP), domestic pig (11\% NISP) and red deer (7.6\% NISP). Other mammalian taxa were identified in small numbers and together comprise less than 14\% of NISP. Red deer is the best represented game species. Wild pig, roe deer and auroch were also hunted.

The ovicaprine body-part frequencies show considerable variation ( $c f$. Table 1). Mandibles, isolated teeth and metapodials are the most common, comprising approx. 70\% of identified ovicaprine bones. Tibiae and radii are well represented, while all other elements account for less than ten fragments (maxilla, femur, pelvis), respectively, and less than five (e.g., horn, humerus, phalanges, etc.). Regarding the frequency of cattle body-parts, phalanges and isolated teeth are the most frequent skeletal elements, followed by metapodials, mandibles and astragali. The most frequent skeletal elements of domestic pig are scapulae, mandibles and ulnae, while only one pig metapodial bone was found in the assemblage. The most numerous skeletal elements of red deer are fragments of antlers and extremity bones.

Human modifications to this assemblage, apart from their use for producing artefacts, were butchery marks and burns. These marks are observed on approximately $5 \%$ of specimens from the site. Butchering marks are observed on the bones of almost all species (except for fox, roe deer, wild pig and marten). Cattle-sized specimens, primarily domestic cattle and red deer, have the most butchering marks, the vast majority being cut marks. Disarticulation is the most evident type of mark, with cuts concentrated around the major limb joints. Filleting marks on long-bone shafts and ribs are also common. Cuts on dog bones are recognisable as butchery marks on radius and ulna, suggesting that dog meat was occasionally consumed (Fig. 2).

Domestic animals played the most important role in the economy. Vitkovo is a rare example of a Late Neolithic site in Serbia showing intensive exploitation of ovicaprines, and the widely accepted strategy of their exploitation was also present here: sheep were herded in large numbers, with a few goats kept alongside. Cattle were more often the focus of exploitation in this period at other sites (e.g., Gomolava, Clason 1979; Divostin, Bökönyi 1988; VinčaBelo Brdo, Dimitrijević 2006; Crkvine, Blažić, Radmanović 2011). The Vitkovo site has a very favourable geographical position, being located in the fertile Župa Valley, which is protected from cold winds by high mountains. The temperature of this microregion is relatively high throughout the year, and it is possible that these are precisely the conditions which provided a suitable environment for herding sheep and goats, as compared to other Late Vinča sites with more humid and colder climates (Bulatović 2011.247).

The age structure of domestic animals at Vitkovo indicates a strategy of exploitation primarily for meat

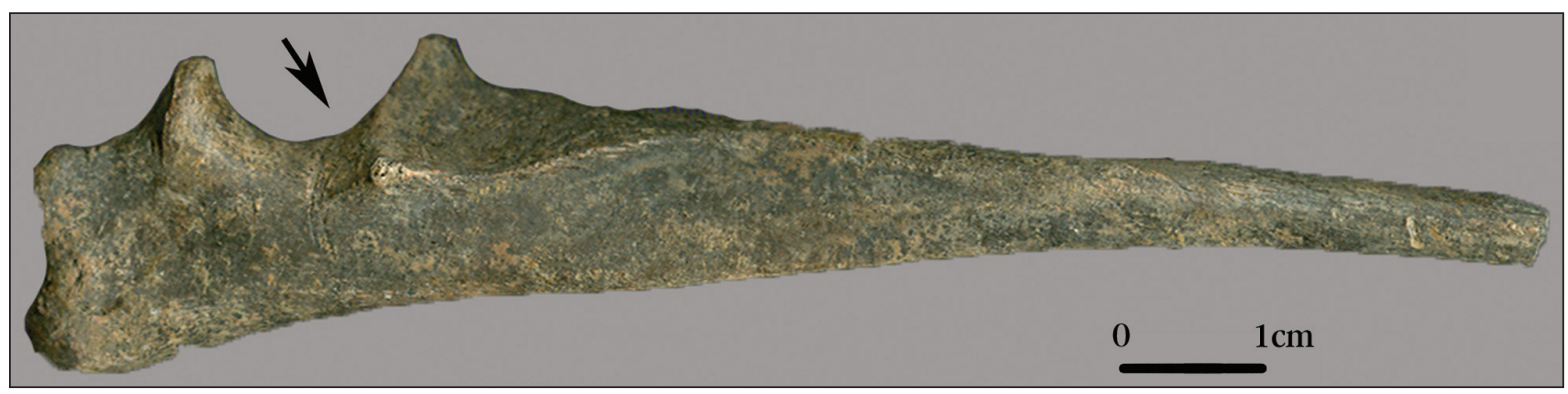

Fig. 2. Left hyoid bone of red deer (Cervus elaphus) with butchering marks. 


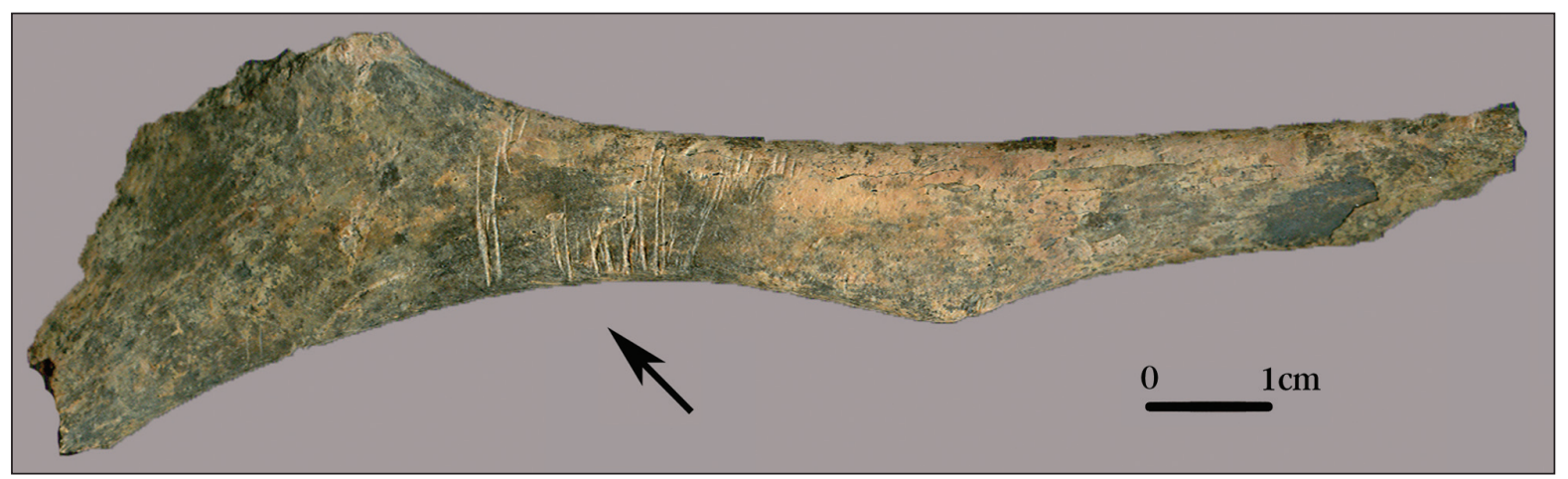

Fig. 3. Right ulna of dog (Canis familiaris) with butchering marks.

consumption. Sheep and goat were slaughtered between 18 and 30 months of age, when they reach optimum weight gain (Bulatovic 2011.241). Hunting also focused mainly on providing meat, as adult individuals were killed in general. The presence of nonmeat bearing bones shows that animals were hunted in the vicinity and often brought to the site whole, where they were butchered. One red deer hyoid with cut marks (Fig. 3) indicates that primary butchering was practiced at the site at least occasionally. Except for meat, animals may also have been hunted for other raw materials, such as skin; a small number of fur-bearing animals should also be mentioned.

\section{The Vitkovo bone tool assemblage}

The feature excavated at Vitkovo also yielded a relatively high number of bone artefacts (approx. 50 items). These were generally made from various mammal bones, but red deer antler, boar tusk and mollusc shell also occur ( $c f$. Table 1). The long bones and ribs of medium-sized ungulates, mainly sheep/ goat, were preferred, while large ungulate bones were also used to a lesser extent. Red deer antlers were used shed, and probably collected in the neighbouring area. Also, six Spondylus shell fragments were discovered.

Débitage phases (cf. Provenzano 2004) are more difficult to reconstruct, but they probably include breaking as well as splitting along the incised groove. The techniques used in the façonnage phases observed on this material include cutting with different flint tools, scraping and burnishing. The final shaping of objects includes polishing, and, in one example only, perforation by flint borer.

The artefacts were classified into several groups according to the overall shape and mode of use of the working edge: I. pointed objects; II. cutting tools; III. burnishing tools; IV. percussion tools; V. objects of special use; VI. decorative items; VII. non-utilitarian objects; and VIII. incomplete pieces ( $c f$. Vitezović 2007.60-82; 2011a.61-68).

The group of pointed objects (I) is the most numerous and consists of two tool types, awls (medium points) and heavy points. Awls were represented by two subtypes: those made from long bones and those made from ribs. Awls from long bones were made by longitudinally splitting medium-size ungulate long bones, in most, if not all cases, the metapodial bone of sheep/goat (Figs. 4, 5). The final shape was obtained by cutting with a flint tool and polishing with a fine-grained abrasive implement. Sometimes an epiphysis segment is preserved on the basal part. The tips, originally sharp, became blunt from use in most cases. The second subtype comprises awls made from split ribs, shaped by cutting, burnishing and polishing (Fig. 6). The use wear on both subtypes consists of intense polish and shine, the spongy tissue on lower surface being often abraded on rib awls, suggesting they were used on soft, organic materials, such as leather and hides (cf. Maigrot 2003).

Several heavy points made from various raw materials were also found: antler, boar's tusks, and bone. Traces of manufacture were poorly preserved, and only polish and wear may be observed of use traces.

Cutting tools (II) were found in low numbers: only one chisel made from a red deer metapodial bone was found, and a knife made from a boar's tusk.

The group of burnishing tools (III) includes two types, spatulae and scrapers. The spatulae were made from antler cortex segments, heavily abraded from use. The scrapers were made from rib segments, irregular in shape and also heavily abraded. These tools too were used on soft, organic materials, probably on leather and hide. No percussion tools were discovered. 
Among the artefacts for special use (V), one spoon made from antler cortex segment, with a long, flat handle and slightly concave upper part, should be mentioned (Fig. 7). Also, several working surfaces were found, all with traces of intensive use, polish, shine and fine striations, suggesting they were used on soft, organic materials, such as leathers and hides.

The group of decorative objects (VI) included one fragmented pendant and five shell bracelets. The pendant was made from segments of antler cortex; it was in the form of an elongated rectangular plate and had a broken perforation on the top. Bracelets were also found fragmented, with surfaces heavily destroyed by poor taphonomic conditions. They were made from Spondylus shell and their simple shape is the same as numerous other artefacts of this kind found throughout prehistoric Europe ( $c f$. Séfériadès 2010). Non-utilitarian artefacts were not discovered.

The last group - of unfinished items and manufacture debris - was particularly interesting. Several segments of longitudinally split long bones with incised grooves were discovered, as well as pieces with traces of burnishing and polishing. Manufacture debris is very significant, since it is often unnoticed if the faunal assemblage is not examined carefully. These finds not only helped to reconstruct the sequences of the operational chain related to manufacture, but also provide indirect evidence of the existence of a workshop at the Vitkovo settlement.

The bone industry at Vitkovo did not differ significantly from the Vinča culture bone industries in terms of raw material choice, manufacturing techniques and typology, although it yielded two unique pieces made from antler, the spoon and the pendant.

\section{Discussion}

For a long time, bone artefacts were completely ignored, or only the most interesting items were in-

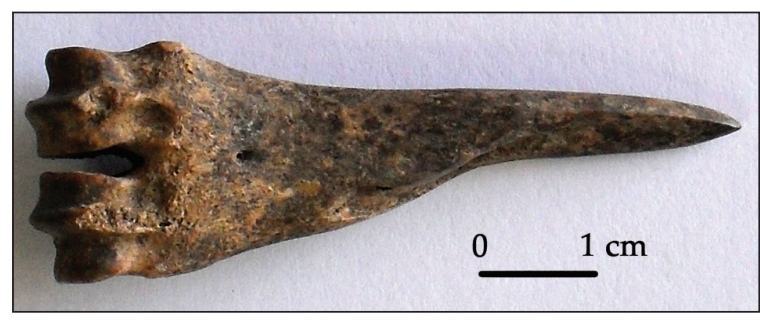

Fig. 4. Awl from ovicaprine metapodial, with entire distal epiphysis preserved at the basal part as a handle.

cluded in publications. This situation began to change slowly in the second half of the $20^{\text {th }}$ century; so, although bone industry is no longer marginalised today, many questions remain unexplored. One reason bone industry has been under-explored may be due to difficulties in distinguishing naturally modified bones from tools, except for items made with special care, and also because bone industry gives the impression of the ad hoc use of kitchen debris. Such a view - that the first bone to hand was used - persists to a certain extent.

The low level of knowledge on bone industry led to some conclusions that were not corroborated by adequate data. It was suggested, for example, that bones were split longitudinally during manufacture in order to 'save' on raw materials, although there is no evidence of insufficient quantities of bone, and the longitudinal splitting also serves to make the final product (awl or fine pointed tool) thinner, finer and sharper. Hypotheses also proposed that roe deer bones were 'preferred', although roe deer has been found in very low proportions at most sites, and tools from roe deer bone, rarely found, have no special characteristics to suggest they were 'valued' (such as very long use, numerous episodes of repair, etc.).

For most Vinča culture bone industries (Divostin, Lyneis 1988; Selevac, Russell 1990; Drenovac and Slatina, Vitezović 2007; Jakovo-Kormadin, Vitezović 2010), several common traits may be outlined: bones are predominant, and although antler ratios vary

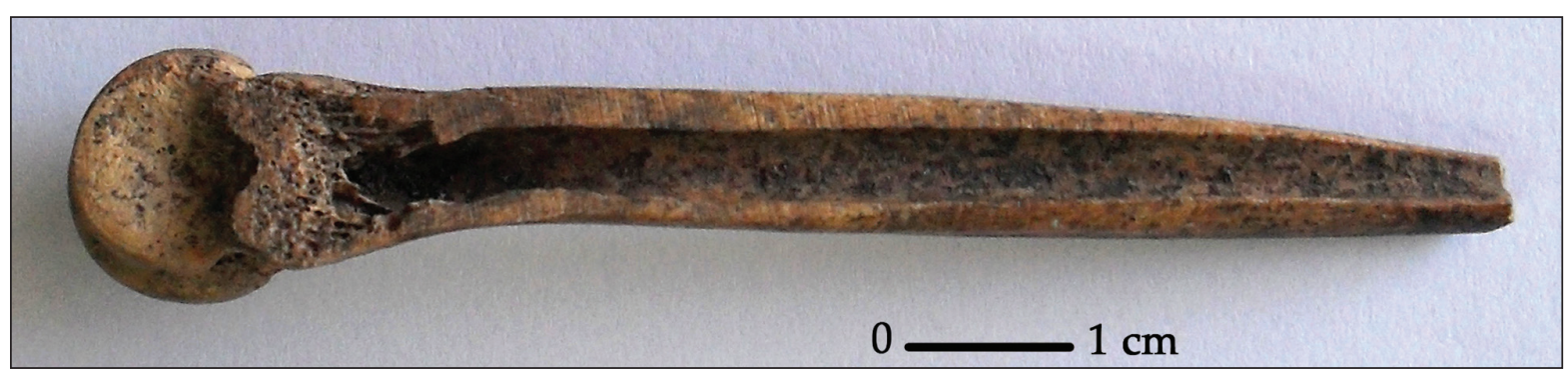

Fig. 5. Awl from longitudinally split ovicaprine metapodial, with half of distal epiphysis preserved at the basal part as a handle. 


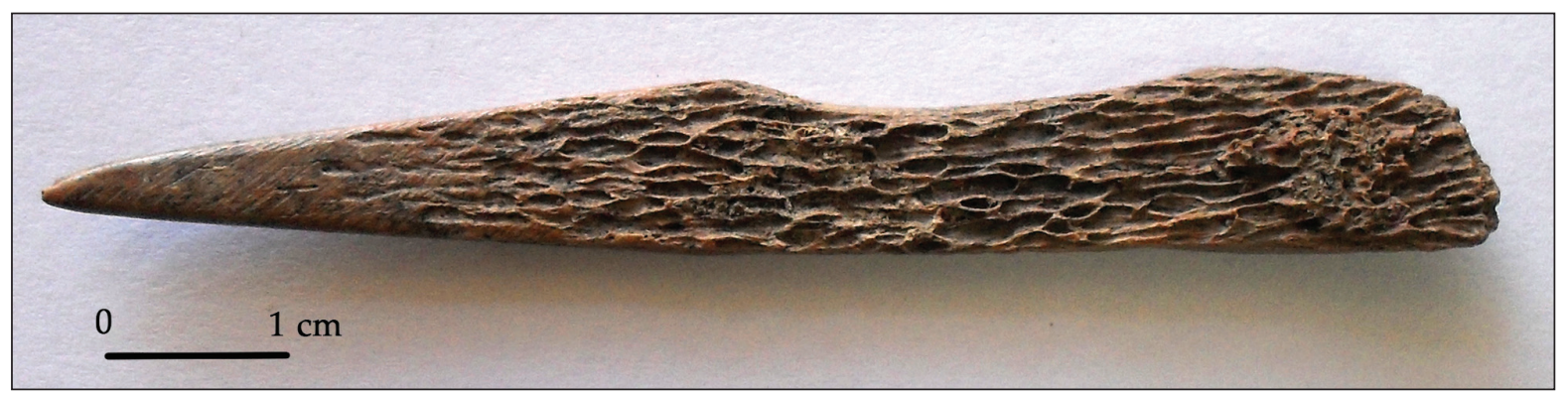

Fig. 6. Awl made from split rib.

from site to site, they rarely exceed $50 \%$. Teeth are rarely used, with boar tusks being used only for tools, while other teeth were perforated and used as decorative items. Mollusc shells also occur, again, in different ratios from site to site, and several species have been recorded: Spondylus, Glycimeris, Cardium and Dentalium (all four have been confirmed only at Vinča-Belo Brdo, see Srejović, Jovanović 1959). Metapodials prevail, the most common being from medium-sized ungulates (sheep, goat, rarely identified roe deer), followed by ribs. Also, different segments of unidentified long bones were used, and the occurrence of astragals should be noted. Some skeletal elements are rare, such as mandibles, or almost never used, such as cranial bones. Large ungulate bones are less common, and pig bones are almost non-existent.

In the Vitkovo bone industry, long bones were the most commonly used skeletal elements. Metapodials dominate, and various segments from un-identified long bones were also found (Figs. 4, 5). Judging from the diameter and wall thickness, these were long bones from medium-size animals, most probably metapodial and perhaps also tibiae. Only one ulna was identified with certainty, while other long bones (humeri, radii, etc.) present in the faunal record were not used for tools.

Metapodial bones are the first to be removed during primary butchering (cf. Olive 1987), but at the same time they have adequate physical and mechanical properties: generally, long bones may be easily split and made into a tool with sharp, but resistant pointed tip (for manufacturing techniques, $c f$. Murray 1979). Ungulate metapodials above all seem to have been very attractive to prehistoric people; the oval condylus of the distal epiphysis is often preserved as a handle (this very type, a pointed tool with distal epiphysis on metapodial, is present in prehistory from the Natufian period, where gazelle bones were used - cf. Stordeur 1988.5-8; le Dosseur 2010 - to the Neolithic and later periods throughout Europe e.g., Voruz 1984.73-5, Fig. 24).

Ulnae also have an epiphysis that may be used as a handle, and pointed tools from ulnae are known from Neolithic sites in Western Europe (e.g., Pascual Benito 1998.46). In Starčevo culture, they may occur occasionally (e.g., at Donja Branjevina, Vitezović 2011a.82), but they are almost non-existent at Vinča sites.

Ribs are the next most common skeletal elements. Both ribs and metapodials were split longitudinally (Fig. 6). However, since the results were slender, sharp pointed tools, it may be assumed that the purpose of splitting was to create a thinner object, and not to save on material. Several pieces with 'mistakes' (long bone shafts with traces of groove, split somewhat irregularly and discarded) also confirm that there was no need to save raw materials, as they could have been easily repaired by abrasion. Also, the spongy tissue on the lower surface of rib

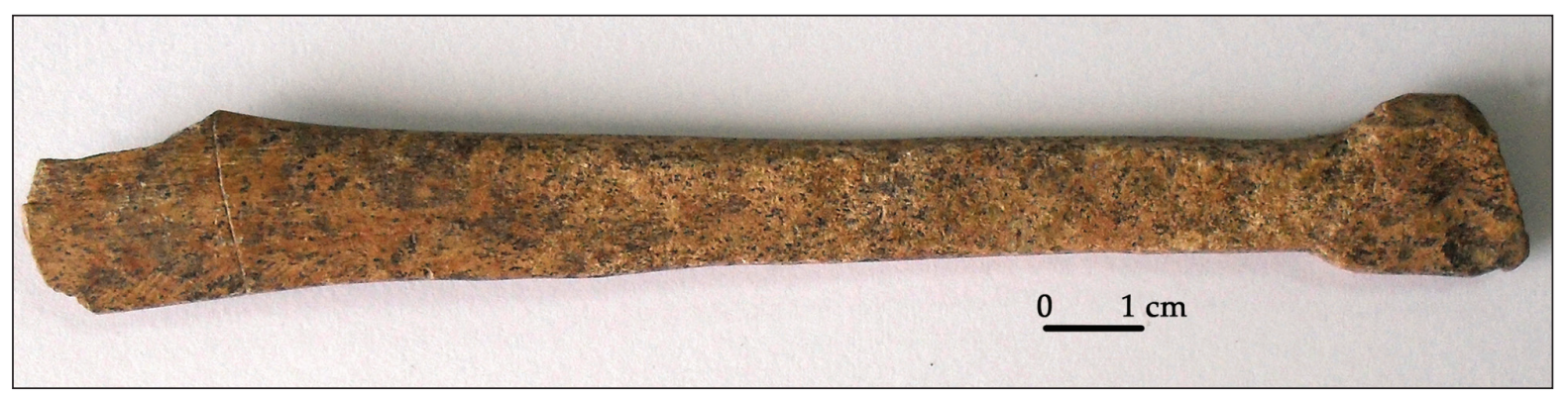

Fig. 7. Spoon made from red deer antler segment. 
tools is usually heavily abraded from use, suggesting such a coarse surface was needed (especially in the case of scrapers).

Other skeletal elements are practically non-existent in tool assemblages. Apart from ribs, no other flat bones were noted, nor short bones, although on other Vinča culture sites worked astragals may occur in relatively low numbers (e.g., at Selevac, $R$ Russell 1990.538-9; Divostin, Lyneis 1988.313-5; Slatina, Vitezović 2007.98-100; Drenovac, Vitezović 2007.157-8).

It should also be mentioned that cranial bones were not used (only one was reported from Selevac, Russell 1990.697). Occasionally, mandibles were used at some Vinča culture sites; they are mentioned at Selevac (Russell 1990.540), and Opovo (Russell 1993.171), but in all of these cases these are expedient tools. Mandibles can be successfully used for tools, as can be seen from some examples from Neolithic sites in France (cf. Maigrot 2003.24).

Bones were obtained from animals that had been killed presumably mainly for food. There is no evidence of the use of bones from discovered dead animals (such as taphonomic traces preceding manufacture traces). On Vitkovo, ovicaprines dominate in the faunal record and, at the same time, ovicaprine bones provided the main raw material for tools. At the majority of other Vinča culture sites, cattle is the dominant domestic species (e.g., Selevac, Legge 1990; Divostin, Bökönyi 1988), and ovicaprine bones also prevail as raw material. This suggests that the choice of ovicaprine bones was not linked to their relative abundance, but that it was the result of deliberate choice.

Antlers were the only skeletal elements of the cranium used systematically as raw material. They were also obtained in a completely different manner from bones. At most Vinča sites, shed antlers are used, although there are some examples of antlers taken from killed animals. For example, at Divostin (where the wild fauna is found in extremely low percentages, about 15\% - Bökönyi 1988.420), a very rich antler industry was discovered, with several heavy percussion tools made from the basal segments of shed antlers; however, one artefact was made from bois du massacre, and one piece of raw material (with traces of tine removal) was also from a killed animal. Antler artefacts are not numerous at Vitkovo, and generally come from segments of smaller dimensions (mainly from cortex pieces; Fig. 7), sugge- sting that antlers were not abundant. Only one antler fragment without traces of manufacture or use was discovered in the faunal record.

The antlers that were used are almost exclusively from red deer. Roe deer antlers were rarely used for tools, and are completely absent from some sites. Different ratios of antlers at particular Vinča culture sites (a high number at Jakovo-Kormadin, relatively low at Slatina) may be the result of different strategies of exploiting neighbouring areas (for antler procurement) and/or of different uses (in most cases, these are heavy tools, probably intended for woodworking).

Decorative items reveal a somewhat different picture of the exploitation of osseous raw materials. The materials are often exotic, such as marine shells (six specimens found at Vitkovo), or related to an area outside the settlement in some other ways, e.g., the perforated teeth of wild animals ( $c f$. red deer canine from Selevac, Russell 1990.pl. 14.7), or they were made from antler, such as the pendant from Vitkovo, or several decorative items from Selevac (Russell 1990.534). Perhaps the very origin of raw material was also important (domestic $v$ s. wild, sensu Hodder 1990).

\section{Conclusion}

Despite some misconceptions about the osseous industry as an ad hoc use of kitchen debris, a careful analysis of the raw material selection in the case study of the Vinča culture site of Vitkovo revealed a different picture.

The skeletal elements and species were carefully chosen in a planned and systematic way, perhaps even separated and set aside already during primary butchering. Although some expediency in raw material selection may occur from time to time, the Vinča culture bone industry is generally planned, revealing the systematic use of specific skeletal elements for determined tool types.

Metapodial bones were used most commonly, followed by other long bones and ribs, generally from ovicaprines. Other bones may have occasionally been used, such as astragals, but some bones were almost never transformed into artefacts (such as cranial bones). Large ungulate bones occur rarely, and pig bones seem to have been avoided.

Such a choice of raw materials is consistent with their mechanical and physical properties and with 
the desired final products (sharp tip, heavy percussion tool). The avoidance of some skeletal elements and some species (cranial bones, pig bones), however, is difficult to explain. Some degree of cultural preference for certain skeletal elements and species is beyond doubt (e.g., preferred choice of wild spe- cies and exotic raw materials for decorative items), but still more evidence is needed for a thorough analysis of the degree of influence of cultural reasons on technological choices, as well as their meaning and symbolic value.

\section{ACKNOWLEDGEMENTS}

We would like to thank to Ljubiša Vasiljević and other colleagues from Narodni muzej Kruševac for entrusting us with the material and the help they provided during our work. This paper is the result of work on the projects 'The archaeology of Serbia: cultural identity, integrational factors, technological processes and the role of the central Balkans in the development of the European prehistory', no. OI 177020, and 'The bioarchaeology of ancient Europe: humans, animals and plants in the prehistory of Serbia', no. III 47001, funded by the Ministry for Education and Science.

\section{$\therefore$}

\section{References}

Antonović D. 1997. Use of Light White Stone In the Central Balkans Neolithic. Starinar XLVIII: 33-39.

Biró T. 1998. Stones, Numbers - History? The Utilization of Lithic Raw Materials in the Middle and Late Neolithic of Hungary. Journal of Anthropological Archaeology 17(1): 1-18.

Blažić S., Radmanović D. 2011. Fauna kasnovinčanskih staništa Crkvine i Belež. Kolubara 5: 239-248.

Bökönyi S. 1988. Neolithic fauna of Divostin. In A. McPherron, D. Srejović (eds.), Divostin and the Neolithic of central Serbia. University of Pittsburgh. Pittsburgh: 419-445.

Borrello M., Micheli R. 2004. Spondylus gaederopus, gioiello dell'Europa preistorica. Preistoria Alpina 40 (suppl. 1): 71-82.

Bulatović J. 2011. Ostaci životinja iz kasnovinčanske jame na nalazištu Vitkovačko polje. Kruševački zbornik 15: 237-272.

Čađenović G. 2007. Trifunovića jama - jama iz vinčanskog perioda na lokalitetu Vitkovačko polje. Župski zbornik 2: 203-217.

Čađenović G., Rašković D. and Bugar M. 2003. Vitkovačko polje u praistoriji. Naselje vinčanske kulture. Narodni muzej Kruševac. Kruševac.

Cavruc V., Harding A. 2012. Prehistoric production and exchange of salt in the Carpthian-Danube Region. In V. Nikolov, K. Bacvarov (ed.), Salt and Gold: The Role of Salt in Prehistoric Europe. Proceedings of the International Symposium (Humboldt-Kolleg) in Provadia, Bulgaria 30 September - 4 October 2010. Verlag Faber. Provadia and Veliko Tarnovo: 173-200.

Choyke A., Schibler J. 2007. Prehistoric bone tools and the archaeozoological perspective: research in Central Europe. In C. Gates St-Pierre, R. Walker (eds.), Bones as tools: current methods and interpretations in worked bone studies. BAR IS 1622. Archaeopress. Oxford: 51-65.

Clason A. 1979. The farmers of Gomolava in the Vinča and La Tène period. Rad Vojvođanskih muzeja 25: 60-114.

Dimitrijević V. 2006. Vertebrate fauna of Vinča-Belo Brdo (Excavation campaigns 1998-2003). Starinar LVI: 245269.

Dimitrijević V., Tripković B. 2002. New Spondylus findings at Vinča-Belo Brdo 1998-2001 campaigns and the regional approach to problem. Starinar LII: 48-62.

2006. Spondylus and Glycymeris bracelets: trade reflections at Neolithic Vinča-Belo Brdo. Documenta praehistorica 33: 237-252.

Dixon J. E., Cann J. R., Renfrew C. 1968. Obsidian and the Origins of Trade. Scientific American 218(3): 38-46.

le Dosseur G. 2010. The Neolithisation in Southern Levant: Impact of animal herding on the exploitation of bone materials, from retinence to adoption of domestic herds. In A. Legrand-Pineau, I. Sidéra, N. Buc, E. David and V. Scheinsohn, Vivian (eds.), Ancient and Modern Bone Artefacts from America to Russia. Cultural, technological and 
functional signature. BAR IS 2136 Archaeopress. Oxford: 17-30.

du Gardin C. 2002. L'ambre et sa circulation dans l'Europe protohistorique. In J. Guilaine (ed.), Matériaux, productions, circulations du Néolithique à l'Age du Bronze. Editions Errance. Paris: 213-235.

Gurova M. 2011. Prehistoric flint assemblages from Bulgaria: a raw material perspective. In Orient şi Occident. Cultură şi civilizatie la Dunărea de Jos, XXVIII. East and West. Culture and civilisation on the lower Danube. Muzeul Dunării De Jos. Călăraşi: 96-115.

Guthrie D. 1983. Osseus projectile points: biological considerations affecting raw material selection and design among paleolithic and Paleoindian peoples. In J. CluttonBrock and C. Grigson (eds.), Animals and Archaeology 1: Hunters and their prey. BAR IS 163. Oxford: 273-294.

Hayden B. 1998. Practical and prestige technologies: The evolution of material systems. Journal of archaeological method and theory 5(1): 1-55.

Hodder I. 1990. The domestication of Europe. Basil Blackwell. Oxford.

Inizan M-L., Reduron-Ballinger M., Roche $\mathrm{H}$. and Tixier. J. 1995. Technologie de la pierre taillée. CNRS et Université de Paris. Paris.

Killick D. 2004. Social Constructionist Approaches to the Study of Technology. World Archaeology 36(4): 571578.

Legge A. J. 1990. Animals, Economy, Environment. In R. Tringham and D. Krstić (eds.), Selevac. A Neolithic village in Yugoslavia. UCLA. Los Angeles: 215-242.

Lemmonier P. 1992. Elements for and anthropology of technology. Ann Arbor. Michigan.

1993. Introduction. In P. Lemonnier (ed.), Technological choices: transformation in material cultures since the Neolithic. Routdledge. London: 1-35.

Leroi-Gourhan A. 1964. Le geste et la parole. Éditions Albin Michel. Paris.

1965. Évolution et techniques 1: L'homme et la matière. Éditions Albin Michel. Paris.

1971. Évolution et techniques 2: Milieu et techniques. Éditions Albin Michel. Paris.

Lyneis M. 1988. Antler and bone artifacts from Divostin. In A. McPherron, D. Srejović (eds.), Divostin and the Neo- lithic of central Serbia. University of Pittsburgh. Pittsburgh: 301-323.

Maigrot Y. 2003. Etude technologique et fonctionnellede l'outillage en matières dures animales La station 4 de Chalain (Néolithique final, Jura, France). Unpublished $\mathrm{PhD}$ thesis. Université de Paris I. Paris.

Margaris A. 2012. Reconsidering Raw Material Selection. Skeletal Technologies and Design for Durability in Subarctic Alaska.Journal of Archaeological Method and Theory: DOI 10.1007/s10816-012-9168-x

McGhee R. 1977. Ivory for the Sea Women: the symbolic attributes of a prehistoric technology. Canadian Journal of Archaeology 1: 141-149.

Murillo-Barroso M., Martinón-Torres M. 2012. Amber Sources and Trade in the Prehistory of the Iberian Peninsula. European Journal of Archaeology 15(2): 187-216.

Murray C. 1979. Les techniques de débitage de métapodes de petits ruminants à Auvernier-Port. In H. Camps-Fabrer (ed.), Industrie de l'os et bois de cervidé durant le néolithique et âge des métaux. Première réunion du groupe de travail no. 3 sur l'industrie de l'os préhistorique. Centre national de la recherche scientifique (CNRS). Paris: $27-35$.

Olive C. 1987. Quelques aspects de la technique de débitage des bovidés en boucherie gallo-romaine dans la vallée du Rhône et les Alpes du Nord. Anthropozoologica 1: 77-82.

Palavestra A. 1993. Praistorijski ćilibar na centralnom $i$ zapadnom Balkanu. Srpska akademija nauka i umetnosti. Balkanološki institut. Beograd.

Pascual Benito J. L. 1998. Utillaje óseo, adornos e ídolos neolíticos valencianos. Disputación provincial de Valencia. Valencia.

Provenzano N. 2004. Fiche terminologie du travail des matières osseuses, du paléolithique aux âges des métaux. In D. Ramseyer (ed.), Matières et techniques, Industrie de l'os préhistorique, cahier XI. Société préhistorique français. Paris: 29-37.

Rijkelijkhuizen M. 2010. Tortoiseshell in the $17^{\text {th }}$ and $18^{\text {th }}$ Century Dutch Republic. In A. Legrand-Pineau, I. Sidéra, N. Buc, E. David and V. Scheinsohn, Vivian (eds.), Ancient and Modern Bone Artefacts from America to Russia. Cultural, technological and functional signature. BAR IS 2136. Archaeopress. Oxford: 97-106.

Russell N. 1990. The Bone Tools. In R. Tringham, D. Krstić (eds.), Selevac. A Neolithic village in Yugoslavia. Mo- 
numenta Archaeologica No. 15. Institute of Archaeology Press, UCLA. Los Angeles: 521-548.

1993. Hunting, hearding and feasting: human use of animals in Neolithic Southeast Europe. Unpublished $\mathrm{PhD}$ thesis. University of California. Berkley.

Saile T. 2012. Salt in the Neolithic of Central Europe: production and distribution. In V. Nikolov, K. Bacvarov (ed.), Salt and Gold: The Role of Salt in Prehistoric Europe. Proceedings of the International Symposium (Humboldt-Kolleg) in Provadia, Bulgaria 30 September - 4 October 2010. Verlag Faber. Provadia and Veliko Tarnovo: 225- 238.

Scheinsohn V., Ferretti J. L. 1995. The Mechanical Properties of Bone Materials in relation to Design and function of prehistoric tools from Tierra del Fuego (Argentina). Journal of Archaeological Science 22: 711-717.

Schibler J. 2001. Red deer antler: exploitation and raw material management in neolithic lake dwelling sites from Zürich, Switzerland. In H. Buitenhuis, W. Prummel (eds.), Animals and Man in the Past. Essays in honour of Dr. A. T. Clason emeritus professor of archaeozoology. Rijksuniversiteit Groningen. ARC-Publicatie 41. Groningen: 82-94.

Séfériadès M. L. 2010. Spondylus and long-distance trade in prehistoric Europe. In D. Anthony (ed.), The Lost World of Old Europe: The Danube Valley 5000-3500 BC. The Institute for the study of the Ancient World \& Princeton University Press. New York, Princeton and 0xford: 178-190.

Sellet F. 1993. Chaîne opératoire: the concept and its applications. Lithic technology 18(1-2): 106-112.

Sénépart I. 1993. Quelques remarques à propos de l'exploitation de la faune sauvage dans l'industrie de l'os néolithique du sud-est de la France (Languedoc oriental, basse valléee du Rhône, Provence). Exploitation des animaux sauvages à travers le temps. XIIIème Rencontres Internationales d'Archéologie et d'Historire d'Antibes. IVème colloque international de l'Homme et l'Animal, 15-1617 oct. 1992. Société de Recherche Interdisciplinaire. Éditions APDCA. Juan-les-Pins: 293-301.

Sidéra I. 2000. Animaux domestiques, bêtes sauvages et objets en matières dures animales du rubané au Michelsberg. Gallia Préhistoire 42: 107-194.
Srejović D., Jovanović B. 1959. Oruđe i oružje od kosti i nakit iz Vinče. Starinar IX-X n. s: 181-190.

Stordeur D. 1988. Outils et armes en os du gisement natoufien de Mallaha (Eynan), Israel. Memoires et traveaux du centre de recherche français de Jerusalem n. 6. Association Paléorient. Paris.

Vitezović S. 2007. Koštana industrija u neolitu srednjeg Pomoravlja. Unpublished MA thesis. Faculty of Philosophy. University of Beograd. Beograd.

2010. Neolitska koštana industrija sa lokaliteta Kormadin u Jakovu. Godišnjak grada Beograda LVII: 43-66.

2011a. Koštana industrija u starijem i srednjem neolitu centralnog Balkana. Unpublished $\mathrm{PhD}$ thesis. Faculty of Philosophy. University of Beograd. Beograd.

2011b. Koštana industrija sa lokaliteta Vitkovo-Trifunovići (iskopavanja 2001.godine). Kruševački zbornik 15: 351-376.

Voruz J.-L. 1984. Outillages osseux et dynamisme industriel dans le néolithique jurassien. Cahiers d'archéologie romande n. 29. Lausanne.

Weller 0. 2012. La production chalcolithique du sel à Provadia-Solnitsata: de la téchnologie céramique aux implications socio-économiques. In V. Nikolov, K. Bacvarov (eds.), Salt and Gold: The Role of Salt in Prehistoric Europe. Proceedings of the International Symposium (Humboldt-Kolleg) in Provadia, Bulgaria 30 September - 4 October 2010. Verlag Faber. Provadia and Veliko Tarnovo: 67-87.

Williams-Thorpe 0. 1995. Obsidian in the Mediterranean and Near East: A Provenancing Success Story. Archaeometry 37: 217-248.

Williams-Thorpe 0., Warren S. E, Barfield L. H. 1979. The Sources and Distribution of Archaeological Obsidian in Northern Italy. Prehistoria Alpina 15: 73-92.

Williams-Thorpe 0., Warren S. E. and Courtin J. 1984. The Distribution and Sources of Archaeological Obsidian from Southern France. Journal of Archaeological Science 11: 135-146. 